\title{
A study of evaluation of iron deficiency as a risk factor for febrile seizures
}

\author{
Khurram M.S.A. ${ }^{1}$, Reddy U.N. ${ }^{2}$ \\ ${ }^{1}$ Dr. Mir Sumsam Ali Khurram, Associate Professor, ${ }^{2}$ Dr. U Narayan Reddy, Professor \& Head, both authors are \\ affiliated with Department of Pediatrics, Deccan College of Medical Sciences, Hyderabad, Telangana State, India.
}

Address for Correspondence: Dr. Mir Sumsam Ali Khurram, Associate Professor, Department of Pediatrics, Deccan College of Medical Sciences, P.O. Box Kanchan Bagh, DMRL 'X' Road, Santosh Nagar, Hyderabad, Telangana State, India. E-mail :dr.sakhurram@gmail.com

\begin{abstract}
Objective: To estimate the incidence of seizure of iron deficiency anemia in febrile seizure. To determine the clinical correlates of children with febrile seizures. Methods: In this case, control study was conducted among 126 children of age group between 6 months and 5 years during April 2015 to April 2016. The control case groups were matched based on the family history of febrile seizure, age, sex, and temperature. Blood samples were collected. Measured quantities of serum feritin, hemoglobin, mean corpuscular volume and mean corpuscular hemoglobin were compared. Result: 36 children $(28.5 \%)$ in the febrile Seizure group have positive family history when compared to none among controls. Serum ferritin level in febrile seizure group is found to have $14.5+/-10.6 \mathrm{ng} / \mathrm{ml}$, where as in controls it is $34.9+/-23.3$ $\mathrm{ng} / \mathrm{ml}$. The mean hemoglobin was $9.8+/-1.2 \mathrm{gm} / \mathrm{dl}$ whereas in controls, it was $11.3+/-1.1 \mathrm{gm} / \mathrm{dl}$. The mean corpuscular volume is $76+/-8.5 \mathrm{fl}$, whereas in control it is $79.5+/-7.5 \mathrm{fl}$, which was statistically significant. The mean corpuscular hemoglobin was 27.7+/-3.1pg and for control it was 28.7/3.6 pg. Conclusion: Serum ferritin, $\mathrm{Hb} \%$ and MCV were found to be significant on the lower side in children with febrile seizure when compared to the children who did not have febrile seizure.
\end{abstract}

Keyword: Febrile seizure, Iron deficiency anemia, Serum ferritin, Mean corpuscular volume

\section{Introduction}

Iron deficiency is the most widespread and common nutritional disorder in the world [1]. It is estimated that $30 \%$ of the global population suffers from iron deficiency anemia, and the most of them live in developing countries [2]. In India $9 \%$ of children between 12-36 months have iron deficiency and 30\% of them have progressed to iron deficiency anemia. The incidence of iron deficiency relates to basic aspects of iron metabolism and nutrition [3]. The body of full term new born infant contains about $0.5 \mathrm{~g}$ of iron, compared to $5 \mathrm{~g}$ of iron in adults. A small additional amount is necessary to balance normal losses of iron by shedding of cells. It is therefore necessary to absorb approximately $1 \mathrm{mg}$ daily to maintain positive iron balance in childhood. Between $2 \%$ and $5 \%$ of neurologically healthy infants and children experience at least one, usually simple, febrile Seizure. Febrile

Manuscript received: $14^{\text {th }}$ October 2016

Reviewed: $26^{\text {th }}$ October 2016

Author Corrected; $18^{\text {th }}$ November 2016

Accepted for Publication: $30^{\text {th }}$ November 2016
Seizure recurs in approximately $30 \%$ of those experiencing the first episode in $50 \%$ after 2 or more episodes and in $50 \%$ of infants $<1 \mathrm{yr}$ old at febrile Seizure onset. Although about $15 \%$ of children with epilepsy have had febrile Seizure [4]. Only $2-7 \%$ of them who experience febrile Seizure proceed to develop epilepsy later in life.

A simple febrile seizure [5] is a primary generalized, usually tonic clonic attack associated with fever, lasting for less than 15 minutes and not recurrent within a 24hours period.

A complex febrile Seizure is more prolonged ( $>15$ minute) is focal, and or recurs within 24 hours. Febrile status epilepticus is a febrile Seizure lasting $>$ 30min. Complex febrile Seizure may have an approximately 2 - fold long term increase in mortality, as compared to general population over the subsequent 2 years, probably secondary to coexisting pathology. 


\section{Materials and Methods}

Study design: Prospective, observational case control study.

Study place: Deccan college of Medical sciences, Princess Esra Hospital \& Owaisi group of Hospitals, Hyderabad. Telangana State, India.

Study Period: April 2015 to April 2016

Study Population: Children were admitted to Owaisi group of Hospitals, Hyderabad. Telangana State, India. Ratio of cases control 1:1 (126:126).

Inclusive Criteria : All the consecutive children aged between 6 months and 5 years attending to outpatient department and emergency department for febrile illness were enrolled in this study, Generalized tonic clonic seizures occurring within 24 hours of onset of fever. Seizure lasting for less than 15 mints (meeting the characteristic criteria for febrile Seizures). Single episode of Seizure per febrile illness. Without any postictal neurological deficit.

Exclusive Criteria: (a) Children with Iron supplementation (b) Hematological disorders, Chronic Illness, neurological deficit (c) Previous history of Seizures.

Maneuver: Blood samples were collected and measured quantity of serum ferritin (the single most sensitive tool for evaluating the iron status), hemoglobin (HB), mean corpuscular volume and mean corpuscular hemoglobin were measured and compared. Serum ferritin estimation: Chemiluminescence Immunoassay for quantitative determination of serum ferritin. $2 \mathrm{ml}$ of blood was collected into vacutainers through venipuncture under strict aseptic precaution. serum was separated from cells by centrifugation. The assay is based on micro-plates coated with highly specific anti.ferritin-human antibodies. During the procedure the binding of the analyte, as well as the formation of the sandwich complex and enzymatic color reaction take place in three different reaction phases

Phase 1: Calibrators, control and undiluted patient samples were pipetted together with sample buffer into the wells of the micro plates. Any present ferritin molecules were bound to the inner surface of the wells. After 30 minutes incubation, the micro plate was washed with buffer for removing non-reactive Serum components.

Phase 2: An-antihuman - ferritins horseradish peroxidase conjugate solution was pipetted into the well of the micro plate to recognize the ferritin bound to the immunized anti bodies.

Phase 3: A chromogenic substrate solution containing TBM (3,3 ,5,5 tetramethyl benzidine) dispensed into the wells, during 15 minutes of incubation. The color of the solution was changed to blue. The amount of color was directly proportional to the concentration of ferritin present in the original sample.

Statistical Analysis: The effect of iron status on febrile seizure with odds ratio (OR) and 95\% confidence limits was arrived at using univariate analysis. An odd ratio is considered statistically valid and meaningful if the upper and lower limits of confidence interval do not include unity. The value of OR was considered significant if the probability (p) was $<0.05$.

\section{Results}

During study period 126 children were admitted in pediatric ward.

Table-1: Incidence of febrile seizure.

\begin{tabular}{|c|c|c|c|c|c|c|}
\hline \multirow[t]{2}{*}{ Age } & \multicolumn{2}{|c|}{ Male } & \multicolumn{2}{|c|}{ Female } & \multicolumn{2}{|c|}{ Total } \\
\hline & $\begin{array}{c}\mathrm{N} \\
\text { Frequency }\end{array}$ & $\begin{array}{c}\% \\
\text { Percentage }\end{array}$ & $\begin{array}{c}\mathrm{N} \\
\text { Frequency }\end{array}$ & $\begin{array}{c}\% \\
\text { Percentage }\end{array}$ & $\begin{array}{c}\text { N } \\
\text { Frequency }\end{array}$ & $\begin{array}{c}\% \\
\text { Percentage }\end{array}$ \\
\hline $6 \mathrm{~m}-1$ year & 14 & 11.1 & 10 & 8 & 24 & 19.1 \\
\hline 1 year- 2 years & 40 & 31.7 & 34 & 27 & 74 & 58.7 \\
\hline 2 years-3 years & 20 & 15.9 & 8 & 6.3 & 28 & 22.2 \\
\hline & 74 & 58.7 & 52 & 41.3 & 126 & 100 \\
\hline
\end{tabular}

Table1 Showing the incidence of febrile seizure found in various age groups. The mean age being 18 months. 
Table-2: Family history of febrile seizure in a two groups.

\begin{tabular}{|c|c|c|c|c|}
\hline \multirow{2}{*}{ Group } & \multicolumn{2}{|c|}{ Cases } & \multicolumn{2}{c|}{ Control } \\
\cline { 2 - 5 } & $\begin{array}{c}\mathbf{N} \\
\text { Frequency }\end{array}$ & $\begin{array}{c}\text { N } \\
\text { Percentage }\end{array}$ & $\begin{array}{c}\% \\
\text { Frequency }\end{array}$ & Percentage \\
\hline With positive family History & 36 & 28.5 & N/A & N/A \\
\hline Without positive family History & 90 & 71.5 & N/A & N/A \\
\hline
\end{tabular}

Table 2: Showing that 36 children (28.5\%) in febrile seizures group with positive family History of febrile Seizure when compared to none among controls

Table-3: Mean value of serum ferritin and blood indices in those who had febrile seizure and controls

\begin{tabular}{|c|c|c|c|c|c|c|}
\hline \multirow{2}{*}{ S.No. } & Variable & \multicolumn{2}{|c|}{ Cases } & \multicolumn{2}{c|}{ Controls } & \multirow{2}{*}{ P.Value } \\
\cline { 2 - 6 } & & Mean & S D & Mean & S D & \\
\hline 1 & Serum Ferritin (ng/ml) & 14.5 & 10.6 & 34.9 & 23.3 & 0.001 \\
\hline 2 & $\mathrm{Hb}(\mathrm{gm} \%)$ & 9.8 & 1.2 & 11.3 & 1.1 & 0.001 \\
\hline 3 & $\mathrm{MCV}(\mathrm{f} 1)$ & 76.0 & 8.5 & 79.5 & 7.5 & 0.02 \\
\hline 4 & $\mathrm{MCH}(\mathrm{pg})$ & 27.7 & 3.1 & 28.7 & 3.6 & 0.11 \\
\hline
\end{tabular}

Table-3: Shows that the mean serum ferritin level among febrile Seizure group was found to be $14.5+/-10.6 \mathrm{ng} / \mathrm{ml}$ whereas in controls, it is $34.9+/-23.3 \mathrm{ng} / \mathrm{ml}$, with statistical significance $(\mathrm{P}=0.001)$. The mean hemoglobin $(\mathrm{Hb})$ for cases was $9.8+/-1.2 \mathrm{gm} / \mathrm{dl}$, where as in controls it was $11.3+/-1.1 \mathrm{gm} / \mathrm{dl}(\mathrm{P}=0.001)$. The mean corpuscular volume (MCV) for cases is $76+/-8.5 \mathrm{fl})$ and for control it was $79.5+/-7.5 \mathrm{fl}(\mathrm{P}=0.02)$ which was statically significant.The mean corpuscular hemoglobin $(\mathrm{MCH})$ for cases was 27.7+/-3.1 Pg and for control it was 28.7+/-3.6pg $(\mathrm{P}=0.11)$. Thus the mean serum ferritin, $\mathrm{Hb}$ and $\mathrm{MCV}$ were found to be significantly on the lower side among children with febrile Seizures when compared to the children who did not have febrile seizures which was statistically significant ( $\mathrm{P}$ value). Even though the $\mathrm{MCH}$ was less among children with febrile Seizures, it did not achieve statistical significance

Table-4: Proportion of children with low serum ferritin /blood indices among cases and controls.

\begin{tabular}{|c|c|c|c|c|c|c|c|}
\hline \multirow[t]{2}{*}{ S.No. } & \multirow[t]{2}{*}{ Variable } & & \multicolumn{2}{|c|}{ Cases } & \multicolumn{2}{|c|}{ Controls } & \multirow[t]{2}{*}{ P.Value } \\
\hline & & & $\mathbf{n}$ & $\%$ & $\mathbf{n}$ & $\%$ & \\
\hline \multirow[t]{2}{*}{1} & \multirow[t]{2}{*}{ Serum Ferritin (ng/ml ) } & $<10$ & 82 & 65.1 & 30 & 23.8 & \multirow{2}{*}{0.001} \\
\hline & & $>10$ & 44 & 34.9 & 96 & 76.2 & \\
\hline \multirow[t]{2}{*}{2} & \multirow[t]{2}{*}{ Hemoglobin $(\mathrm{gm} \%)$} & $<11$ & 102 & 80.9 & 38 & 30.1 & \multirow{2}{*}{0.001} \\
\hline & & $>11$ & 24 & 19.04 & 88 & 69.9 & \\
\hline \multirow[t]{2}{*}{3} & \multirow[t]{2}{*}{$\mathrm{MCV}(\mathrm{fl})$} & $<70$ & 46 & 36.5 & 16 & 12.7 & \multirow{2}{*}{0.003} \\
\hline & & $>-70$ & 80 & 63.5 & 110 & 87.3 & \\
\hline \multirow[t]{2}{*}{4} & \multirow[t]{2}{*}{$\mathrm{MCH}(\mathrm{Pg})$} & $<24$ & 20 & 15.0 & 18 & 14.3 & \multirow{2}{*}{1.00} \\
\hline & & $>/-24$ & 106 & 84.1 & 108 & 85.7 & \\
\hline
\end{tabular}

Table-4: Shows that 82 children $(65.1 \%)$ with febrile Seizure have serum ferritin level $<10 \mathrm{ng} / \mathrm{ml}$ whereas only 30 children $(23.8 \%)$ in control group have ferritin level $<10 \mathrm{ng} / \mathrm{ml}$ which was statistically significant $(\mathrm{P}=0.001)$. The number of children with hemoglobin $<11 \mathrm{gm} / \mathrm{dl}$ is $102(92.7 \%)$ in febrile Seizures group where as among controls it is only 38 $(30.1 \%)(\mathrm{P}=0.001)$. The mean corpuscular volume $<70 \mathrm{f} 1$ was seen in $46(36.5 \%)$ cases, whereas in controls it was only $16(12.7 \%)(\mathrm{P}=0.003) .20$ children $(15.9 \%)$ in cases and 18 children $(14.3 \%)$ in controls have mean corpuscular hemoglobin $<24 \mathrm{pg}(\mathrm{P}=1)$. Thus a significant proportion of children with febrile Seizure have low serum ferritin. However, the proportion of children with low mean corpuscular hemoglobin among those with febrile Seizures and control did not achieve statistical significance. 
Original Research Article

Table-5: Serum ferritin and blood indices among cases and controls: Univariate analysis.

\begin{tabular}{|c|c|c|c|c|c|}
\hline S.No. & \multicolumn{2}{|l|}{ Variable } & Odds ratio & $95 \% \mathrm{Cl}$ & P.Value \\
\hline \multirow[t]{2}{*}{1} & \multirow[t]{2}{*}{ Serum Ferritin $(\mathrm{ng} / \mathrm{ml})$} & $<10$ & 6.0 & $2.7,13.0$ & \multirow{2}{*}{0.001} \\
\hline & & $>/ 10$ & 1.0 & Reference & \\
\hline \multirow[t]{2}{*}{2} & \multirow[t]{2}{*}{ Hemoglobin $(\mathrm{gm} \%)$} & $>11$ & 9.8 & $4.3,22.5$ & \multirow{2}{*}{0.001} \\
\hline & & $<-11$ & 1.0 & Reference & \\
\hline \multirow[t]{2}{*}{3} & \multirow[t]{2}{*}{ MCV (fl) } & $<70$ & 4.0 & $1.6,9.7$ & \multirow{2}{*}{0.003} \\
\hline & & $>-70$ & 1.0 & Reference & \\
\hline \multirow[t]{2}{*}{4} & \multirow[t]{2}{*}{$\mathrm{MCH}(\mathrm{Pg})$} & $<24$ & 1.1 & $0.4,3.0$ & \multirow{2}{*}{1.00} \\
\hline & & $>/-24$ & 1.0 & Reference & \\
\hline
\end{tabular}

Table-5: Shows that the Odd ratios of children with febrile seizures having low serum level were 6, when compared to those who did not have febrile Seizure. Odd ratios of children with febrile seizures having low hemoglobin level were 9.8 when compared to those who did not have febrile seizure. Odd ratios of children with febrile seizures having low mean corpuscular volume was four, when compared to those who did not have febrile seizure. Odd ratios of children with febrile Seizures having low mean corpuscular hemoglobin is 1.1 when compared to those who did not have febrile Seizure which was not statistically significant.

\section{Discussion}

Total 126 cases were studied and analyzed to detect low iron status as a possible risk factors for febrile seizure. In the present study, we found that the peak incidence of febrile seizure occurring during one to two years of age and the main age was 14-18 months of age [7]. Berg et al in their study found that the peak incidence is between 18 and 24 months [8]. As similar to previous studies done by Naveedul Rehman et al reported the peak incidence at 22 months [9]. The present study depicts that the incidence of febrile seizure was slightly higher in boys than in girls and the male: female ratio was 1.4:1. In our study family history of febrile Seizures was seen only in $28.5 \%$ cases.

The mean Serum ferritin level in the study was 14.5 $\mathrm{ng} / \mathrm{ml}$, whereas Daoud et al in their study group from Jordan found that the serum ferritin level was $29.05 \mathrm{ng} / \mathrm{ml}[10]$. It is probably due to fact that the iron deficiency is more prevalent in our country. Daoud et al in their study found that a significant proportion of children with febrile seizures had only low serum ferritin level $[10,11,12]$. The proportion of children with febrile seizures having low hemoglobin mean corpuscular volume and mean corpuscular hemoglobin were not statistically significant.

Whereas our study demonstrates a statistically significant difference in the proportion of children with febrile seizures have not only low serum ferritin, but also low haemoglobin and low mean corpuscular volume, it was similar to the findings reported by
Alfredo pisacane et al [14.15], our study demonstrates an association between iron deficiency and febrile seizures. Thus, iron deficiency is one of the possible risk factor for febrile seizures. Developmental problems, risk of pediatric stroke, the occurrence of febrile seizures and breath holding spells are perhaps the tip of the ice berg, of the neurological consequences of iron deficiency $[16,17]$.

With appropriate recognition, treatment, [1] prevention the neurological sequealae of iron deficiency are entirerly preventable and perhaps reversible.

Recommendations: A follow up study of patients with iron deficiency at the time of a first febrile seizure to determine the incidence of subsequent febrile seizure after treatment for iron deficiency would be of great interest.

\section{Conclusion}

Iron deficiency as a risk factor for simple febrile seizure in children. Serum ferritin level and blood indices are significantly lower in children with febrile seizure as compared to children without febrile seizure suggesting that iron deficient children are more prone to febrile seizures. Early detection and timely correction of iron deficiency may helpful for prevention of febrile seizure in children.

Funding: Nil, Conflict of interest: Nil

Permission from IRB: Yes 


\section{References}

1. Florentino RF, Guirriec R M. Prevalence of nutritional anemia in infancy and childhood with emphasison developing countries. In: A.Stekel (Ed) Iron nutrition in infancy and childhood. Ravan press, New York; 1984; 61-74.

2. Stoltzfus R. Defining iron Deficiency anemia in public health terms, a time for reflection .J Nutr. 2001; $13 ! 565 \mathrm{~S}-567 \mathrm{~S}$.

3. DeMaeyer E, Adiels-Tegman M. The prevalence of anemia in the world. World health state Q.1985;38: 302-16

4. Rantala H, Uhari M. Risk factor for recurrences of Febrile Convulsions. Acta Neurol Scand 1994:90: 207-10.

5. Lozoff B, Georgieff M.K, Iron deficiency and brain development. Semin peditr Neurol.2006:13:158-65.

6. Van der Berg BJ, Yerushalmy J. Studies on convulsive disorders in young children. I. Incidence of febrile and nonfebrile convulsions by age and other factors. Pediatr Res. 1969 Jul;3(4):298-304.

7. Ling S G. Clinical characteristics and risk factors for a complex first febrile convulsion. Singapore Med J. 2001;42: 264-7.

8. Berg AT, Shinnar S, Darefsky AS et al. Predictors of recurrent febrile Seizurs. A prospective cohort study Arch pediatric Addex Med 1997; 151:371-8.

9. Rehman N, Billoo AG, ET Al .Association between iron deficiency and febrile Seizures. J.Coll. Physicians Surg.Pak. 2005;15(6)338-40.

10. Daoud AS, Batchia A, Al-Sheyyab M, Effectiveness of iron therapy on breath holding spells. J.Pediater 1997; 130:547-50.
11. Maliyar A, Rezac MA. Ferritin level in children with and without Febrile Convulsry. Journal of Karmanshah University of Medical Sciences . 2006; 10:2004.

12. Talebian A, Andalibs, Veji 2006; 10:2004.a Moravvaji SA, Vakiliz:Serum Ferrtin level in febrile children with or without Seizure. KAUMS Journal (FEY2)2011;15(H):389.93.

13. Vaswani RK, Dharaskar PG, Kulkarni S, Ghosh K. Iron deficiency as a risk factor for first febrile seizure. Indian Pediatr. 2010 May;47(5):437-9. Epub 2009 Sep 3 .

14. Daoud AS, Batchia A, Abu Esctarsh F et al. Iron status. A possible risk factor for first febrile Seizure. Epilepsia 2002;43:740-3.

15. Pisacane A, Jansone $\mathrm{P}$, Impaliazzo $\mathrm{N}$ et al. Iron deficiency anemia and febrile convulsion .Case control study in children under 2 years Brit Med J 1996; 313-343.

16. Lozoff B, Beard J, connor J, Felt B, Georgieff M, and Schallert T. Long -lasting neural and behavioral effect of iron deficiency in infancy. Nutr Rev. 2006; 64:S34-91.

17. Wigglesworth J.M, Baum H. Iron dependentenzymes in the brain, In: M.B.H. youdim (Ed). Brain iron in neurochemical and behavioral aspects. Taylor. Taylor and Francis, New York, NY; 1988:25-66.

18. Akihisa O, Yoshiko I, Ayako S., Koichi M, Tet sou $\mathrm{K}$ et al. Treatment and out come in patients with febrile convulsion associated with Epileptiform discharges on electro enephalography. Brain Dev.2004;26:241-4.

\section{How to cite this article?}

Khurram M.S.A, Reddy U.N.A Study of evaluation of iron deficiency as a risk factor for febrile seizures. Int. J Pediatr Res. 2016;3(11):826-830.doi:10.17511/ijpr.2016.i11.10. 